\title{
Perbandingan Viabilitas Oosit Pascavitrifikasi pada Dua Tingkat Konsentrasi Sukrosa yang Berbeda
}

\author{
Rini Widyastuti, ${ }^{1,2,3}$ Candrani Khoirinaya, ${ }^{4}$ M. Rosyid Ridlo, ${ }^{5}$ Mas Rizky A. A. Syamsunarno ${ }^{3,6,7}$ \\ ${ }^{1}$ Laboratorium Reproduksi dan Inseminasi Buatan, Departemen Produksi Ternak Fakultas Peternakan, \\ Universitas Padjadjaran, ${ }^{2}$ Program Studi Kedokteran Hewan, Fakultas Kedokteran Universitas Padjadjaran, \\ ${ }^{3}$ Laboratorium Sentral Universitas Padjadjaran, ${ }^{4}$ Adidaya Dermama Bioteknologi, Surakarta, Jawa Tengah \\ ${ }^{5}$ Program Studi Kesehatan Hewan, Departemen Teknologi Hayati dan Veteriner Sekolah Vokasi Universitas \\ Gajah Mada, ${ }^{6}$ Departemen Biokimia dan Biologi Molekuler Fakultas Kedokteran Universitas Padjadjaran \\ ${ }^{7}$ Program Studi Bioteknologi Sekolah Pasca Sarjana Universitas Padjadjaran
}

\begin{abstract}
Abstrak
Vitrifikasi merupakan suatu teknik kriopreservasi tanpa disertai pembentukan kristal es, baik intraseluler maupun ekstraseluler. Tingkat keberhasilan vitrifikasi sangat dipengaruhi oleh jenis dan konsentrasi krioprotektan yang digunakan. Sukrosa merupakan krioprotektan ekstraseluler yang mempunyai peranan dalam menjaga kestabilan membran sel pada saat proses dehidrasi. Tujuan penelitian ini adalah mengkaji efekpenambahan sukrosa dalam dua level konsentrasi yang berbeda pada morfologi dan persentase hidup oosit pascavitrifikasi dengan menggunakan oosit domba yang telah dimatangkan secara in vitro sebagai model. Penelitian dilaksanakan di Laboratorium Riset dan Bioteknologi, Fakultas Peternakan, Universitas Padjadjaran periode September 2016-Desember 2016. Penelitian menggunakan rancangan acak lengkap dengan dua kelompok perlakuan, yaitu penambahan 0,5 $\mathrm{M}$ sukrosa atau 0,65 M sukrosa pada media vitrifikasi. Parameter yang diamati adalah persentase oosit hidup dan morfologi oosit yang mati pascavitrifikasi-pencairan kembali. Hasil yang diperoleh menunjukkan bahwa persentase oosit hidup pascavitrifikasi meningkat $20 \%$ setelah penambahan sukrosa $0,65 \mathrm{M}$. Fraktur zona pelusida merupakan kerusakan morfologi yang banyak ditemukan pada oosit yang divitrifikasi dengan penambahan 0,5 M sukrosa dalam larutan vitrifikasi. Hasil penelitian ini mengindikasikan bahwa penambahan sukrosa $0,65 \mathrm{M}$ sebagai krioprotektan ekstraseluler meningkatkan peluang hidup oositsetelah proses vitrifikasi. [MKB. 2017;49(4):252-8]
\end{abstract}

Kata kunci: Krioprotektan, morfologi oosit, sukrosa, vitrifikasi

\section{Comparison of Oocyte Viability after Vitrification with Two Different Sucrose Concentration Level}

\begin{abstract}
Vitrification is a cryopreservation technique without the formation of ice crystals, both intracellular and extracellular. The success of vitrification depends on the type and concentration of cryoprotectants. Sucrose is one of the extracellular cryoprotectants that play a role in maintaining cell membrane during dehydration process. The purpose of this study was to examine the effect of the addition of two different sucrose concentration levels on the morphology and viability of oocyte after vitrification using matured sheep oocytes as a model. This study was conducted at the Research and Biotechnology Laboratory, Faculty of Animal Husbandry, Universitas Padjadjaran during September-December 2016. The oocytes were randomly assigned into groups with two different concentrations of sucrose in vitrification media: i.e. $0.5 \mathrm{M}$ and $0.65 \mathrm{M}$. The parameters observed were the percentage of live oocytes and the dead oocyte morphology after vitrification-thawing. The results showed that the percentage of live matured oocytes post-vitrification increased by $20 \%$ after the addition of $0.65 \mathrm{M}$ sucrose. Fracture of pellucida zone was the major finding in the post-vitrification dead oocytes in $0.5 \mathrm{M}$ sucrose group. This indicates that vitrification using $0.65 \mathrm{M}$ sucrose as extracellular cryoprotectant presents a higher oocyte survival after vitrification-thawing. [MKB. 2017;49(4):252-8]
\end{abstract}

Key words: Cryoprotectant, oocytes morphology, sucrose, vitrification

Korespondensi: Rini Widyastuti, drh., M.Si, Laboratorium Reproduksi dan Inseminasi Buatan, Departemen Produksi Ternak, Fakultas Peternakan, Universitas Padjadjaran, E-mail: r.widyastuti@unpad.ac.id 


\section{Pendahuluan}

Teknologi reproduksi telah diterapkan secara luas dalam bidang ilmu kedokteran. Pada bidang kedokteran hewan, aplikasi teknologi reproduksi bertujuan untuk konservasi satwa yang hampir punah dan meningkatkan jumlah keturunan bagi hewan yang mempunyai nilai genetik tinggi. Pada bidang kedokteran manusia, teknologi reproduksi diaplikasikan di praktik klinik reproduksi untuk menanggulangi masalah reproduksi pada pasien yang mengalami gangguan fertilitas dan pada penderita kanker. Salah satu teknologi reproduksi berbantuan yang saat ini banyak diminati oleh pasien dengan gangguan fertilitas adalah melalui program in vitro fertilization (IVF). Prosedur rutin yang dilakukan pada klinik reproduksi meliputi inseminasi intrauteri, fertilisasi in vitro, kultur in vitro, kriopreservasi (pembekuan) gamet baik sel gamet maupun oosit, kriopreservasi embrio, dan transfer embrio. Kriopreservasi pada oosit kuranglah populer apabila dibanding dengan kriopreservasi pada sperma maupun embrio. Kriopreservasi oosit lebih sulit dilakukan karena luas permukaan oosit lebih besar dibanding dengan volume sitoplasmanya. Selain itu, oosit juga lebih sensitif terhadap proses pendinginan. ${ }^{1-3}$ Kesulitan lainnya adalah oosit hanya mempunyai satu sel sehingga apabila bagian sel tersebut rusak maka proses perkembangan akan terhenti. Kondisi ini sangat berbeda dari embrio yang telah memiliki banyak sel sehingga apabila ada satu sel yang rusak masih ada kemungkinan sel lain untuk berkembang ke tahapan selanjutnya. Oosit beku akan memiliki nilai tambah yang cukup tinggi apabila setelah proses pencairan kembali masih memiliki morfologi dan struktur organel yang normal. Nilai tambah yang cukup tinggi ini karena struktur organel sangat penting dalam menunjang dan menjalankan aktivitas biologis oosit pada saat fertilisasi dan proses perkembangan menjadi embrio.

Ada beberapa metode kriopreservasi oosit yang sudah berhasil dilakukan di antaranya adalah pembekuan lambat (slow freezing) dan pembekuan cepat (rapid freezing) serta pembekuan sangat cepat (ultra rapid freezing). Oosit yang telah dikembangkan dari metode tersebut menunjukkan hasil fertilisasi dan laju pertumbuhan embrio yang rendah ${ }^{4} \mathrm{Hal}$ ini disebabkan oleh pembentukan kristal es sehingga merusak membran dan organel sel. ${ }^{5}$ Pembentukan kristal es terjadi antara suhu -5 dan $-80^{\circ} \mathrm{C}$ merupakan sumber utama kerusakan oosit. Strategi yang ditempuh untuk meminimalisir efek tersebut adalah dengan penambahan kriopotektan ke dalam media dan pengontrolan terhadap laju perubahan temperatur. Salah satunya adalah dengan mengaplikasikan metode vitrifikasi, kondisi yang cairan tersolidifikasi sehingga dapat mencegah efek letal pada sel. ${ }^{6}$ Pada metode vitrifikasi, oosit melewati zona temperatur yang berbahaya dengan sangat cepat dan waktu pemaparan yang sangat pendek pada temperatur yang berbahaya $15^{\circ} \mathrm{C}$ sampai $-5^{\circ} \mathrm{C}$ sehingga dapat mengurangi kerusakan struktur yang sensitif.

Konsekuensi dari peningkatan laju pembekuan pada proses vitrifikasi adalah penggunaan krioprotektan dengan konsentrasi tinggi untuk meningkatkan viskositas larutan sehingga titik beku larutan akan menurun lebih cepat sehingga membatasi jumlah kristal es yang terbentuk. Akan tetapi, kondisi vitrifikasi membutuhkan penggunaan krioprotektan dengan konsentrasi tinggi yang memungkinkan merusak sel karena stres osmotik atau efek toksik yang ditimbulkan oleh krioprotektan. Salah satu upaya meminimalkan kerusakan tersebut adalah dengan penambahan krioprotektan ekstraseluler dengan konsentrasi yang bertingkat. Sukrosa merupakan jenis krioprotektan ekstraseluler yang sering digunakan pada vitrifikasi oosit sapi ${ }^{7}$ maupun embrio. ${ }^{8}$ Penambahan sukrosa ke dalam medium ekuilibrasi sebelum proses krioprservasi itu menghasilkan peningkatan viabilitas embrio pascapencairan kembali. ${ }^{9}$ Oleh karena itu, tujuan penelitian ini adalah mengkaji efek penambahan sukrosa dengan dua konsentrasi yang berbeda, yaitu 0,65 M dan 0,5 M pada morfologi dan juga persentase hidup oosit pascavitrifikasi. Penelitian ini menggunakan oosit domba sebagai model dan hasil yang diperoleh diharapkan dapat dimanfaatkan untuk kriopreservasi oosit pada pasien-pasien infertilitas pada klinik IVF maupun untuk mengatasi ketersediaan oosit pada program embrio transfer dalam bidang kedokteran hewan.

\section{Metode}

Penelitian ini dilaksanakan di Laboratorium Riset dan Bioteknologi, Fakultas Peternakan, Universitas Padjadjaran. Penelitian dilaksanakan pada bulan September 2016-Desember 2016. Bahan-bahan yang digunakan pada penelitian ini adalah oosit domba lokal yang diperoleh dari ovarium domba lokal yang berasal dari sisa pemotongan domba di Rumah Pemotongan Hewan (RPH) setempat, $\mathrm{NaCl}$ fisiologis $0,9 \%$, 
fetal bovine serum (FBS), tissue culture media 199 (TCM 199), follicle stimulating hormone (FSH), lutealizing hormone (LH), DMSO, EG, sukrosa, $\mathrm{Na}$ bikarbonat, phosphate buffer saline (PBS), carrier vitrifikasi menggunakan alat hemistraw (home-made), mikroskop stereo, dan mikroskop inverted. Media koleksi adalah $\mathrm{NaCl}$ fisiologis ditambah penisilin $100 \mathrm{IU} / \mathrm{mL}$, streptomisin $100 \mu \mathrm{g} / \mathrm{mL}$. Media koleksi oosit adalah modified phosphate buffered saline (mPBS). Media maturasi adalah TCM 199 ditambah penisilin $100 \mathrm{IU} / \mathrm{mL}$, streptomisin $100 \mu \mathrm{g} / \mathrm{mL}$, dan follicle stimulating hormone (FSH) (Sigma, USA) 0,01 $\mathrm{mg} / \mathrm{mL}$. Media maturasi disuplementasi dengan fetal bovine serum (FBS) 10\% (Sigma, USA)

Media yang digunakan untuk ekuilibrasi oosit adalah 7,5\% v/v DMSO + 7,5\% v/v EG dalam media dasar PBS yang telah ditambahkan dengan FBS 20\%. Terdapat dua jenis media vitrifikasi yang digunakan. Media vitrifikasi yang pertama adalah $15 \% \mathrm{v} / \mathrm{v}$ DMSO + 15\% v/v EG $+0,5 \mathrm{M}$ sukrosa dalam media dasar PBS yang telah ditambahkan dengan FBS 20\%. Media vitrifikasi yang kedua adalah $15 \% \mathrm{v} / \mathrm{v}$ DMSO $+15 \% \mathrm{v} / \mathrm{v}$ EG+ 0,65 M sukrosa dalam media dasar PBS yang telah ditambahkan dengan FBS $20 \%$. Penambahan sukrosa 0,5 M dalam media vitrifikasi digunakan sebagai kontrol karena merupakan metode yang telah diaplikasikan untuk vitrifikasi oosit. ${ }^{10}$

Ovarium domba dipotong di Rumah Potong Hewan untuk keperluan konsumsi daging. Ovarium disimpan dalam termos dengan media transportasi ( $\mathrm{NaCl}$ fisiologis) suhu $30-35^{\circ} \mathrm{C}$ dan dibawa ke laboratorium. Koleksi oosit dilakukan dalam rentang waktu 3-4 jam sejak hewan dipotong. Ovarium dicuci dengan media koleksi, oosit dikoleksi dengan metode pencacahan dan dicuci 3 kali, pencucian terakhir dengan media pematangan TCM 199. Oosit yang mempunyai sel-sel kumulus kompleks lebih dari dua lapis dengan sitoplasma homogen yang digunakan sebagai objek penelitian.

Maturasi oosit secara in vitro dilakukan dalam media tissue culture medium (TCM) 199 (Sigma, USA) ditambahkan FBS 10\%, $10 \mathrm{IU} / \mathrm{mL}$ pregnant mare serum gonadotrophin (PMSG) (Intergonan, Intervet Deutschland $\mathrm{GmbH}$ ), $10 \mathrm{IU} / \mathrm{mL}$ human chorionic gonadotrophin (hCG) (Chorulon, Intervet international B.V. Boxmeer-Holland), dan $50 \mu \mathrm{g} / \mathrm{mL}$ gentamycin (Sigma, USA) selama 24 jam. Oosit dicuci sebanyak tiga kali dengan media PBS, kemudian oosit dipindahkan ke dalam $100 \mu \mathrm{L}$ tetes media pematangan yang dibuat pada cawan petri steril lalu ditutup dengan mineral oil. Setiap tetes media pematangan berisi sekitar 10-15 oosit. Selanjutnya, oosit diinkubasi selama 24 jam dalam inkubator pada suhu $38,5^{\circ} \mathrm{C}, 5 \% \mathrm{CO}_{2}$, dan kelembapan $95 \% .{ }^{11}$ Selanjutnya, dilakukan evaluasi atas kematangan oosit. Tingkat kematangan oosit dievaluasi dengan melihat pengembangan sel-sel kumulus dan terdapat badan kutub pertama.

Oosit yang telah matang dibagi menjadi 2 kelompok, yaitu (i) oosit yang dibekukan dalam media vitrifikasi yang mengandung kombinasi EG 15\% v/v + DMSO 15\% v/v + 0,5 M sukrosa dan (ii) oosit yang dibekukan dalam media vitrifikasi yang mengandung kombinasi EG 15\% v/v + DMSO 15\% v/v + 0,65 M sukrosa. Oosit diekuilibrasi selama kurang lebih 10-12 menit di dalam larutan ekuilibrasi ${ }^{12}$ yang mengandung $7,5 \%$ v/v EG $+7,5 \%$ v/v DMSO, kemudian dipaparkan ke dalam medium vitrifikasi selama 30 detik, sesudah itu dimasukkan ke dalam hemistraw (buatan sendiri) dengan volume $\pm 2 \mu \mathrm{L}$ pada suhu ruangan. Alat ini kemudian dicelupkan ke dalam nitrogen cair dan kemudian disimpan di dalam tangki nitrogen cair sebelum dicairkan kembali.

Oosit itu dicairkan kembali dengan cara memasukkan hemistraw ke dalam suatu media pencairan dengan 3 pencairan yang berbeda, yaitu 0,5 M sukrosa, 0,25 M sukrosa, dan 0,15 M sukrosa. Setelah dihangatkan, oosit dikultur dalam inkubator $\mathrm{CO}_{2}$ selama 3-4 jam untuk melihat apakah oosit hidup (survival rate) atau mati (lisis). Evaluasi viabilitas oosit domba setelah vitrifikasi dilakukan dengan mengkultur secara in vitro pada media kultur selama tiga jam untuk melihat ekspansi kembali sel-sel, keutuhan sitoplasma, dan kondisi zona pelusida oosit.

Penelitian memakai metode eksperimental laboratorium dengan rancangan acak lengkap yang dibagi menjadi dua kelompok perlakuan. Perlakuan yang dicobakan adalah penambahan 0,5 M sukrosa atau 0,65 M sukrosa pada media vitrifikasi. Parameter yang diamati adalah oosit dengan morfologi normal pascavitrifikasipencairan kembali dan morfologi oosit mati yang ditunjukkan oleh degenerasi oosit dan fraktur zona pelusida pascavitrifikasi pencairan kembali Data dianalisis dengan menggunakan uji t.

\section{Hasil}

Morfologi oosit pascapencairan kembali dapat dilihat dari kondisi zona pelusida dan sitoplasma. Pada gambar tampak bahwa oosit yang mati ditandai dengan keadaan zona pelusida yang fraktur dan pengerutan sitoplasma ataupun 


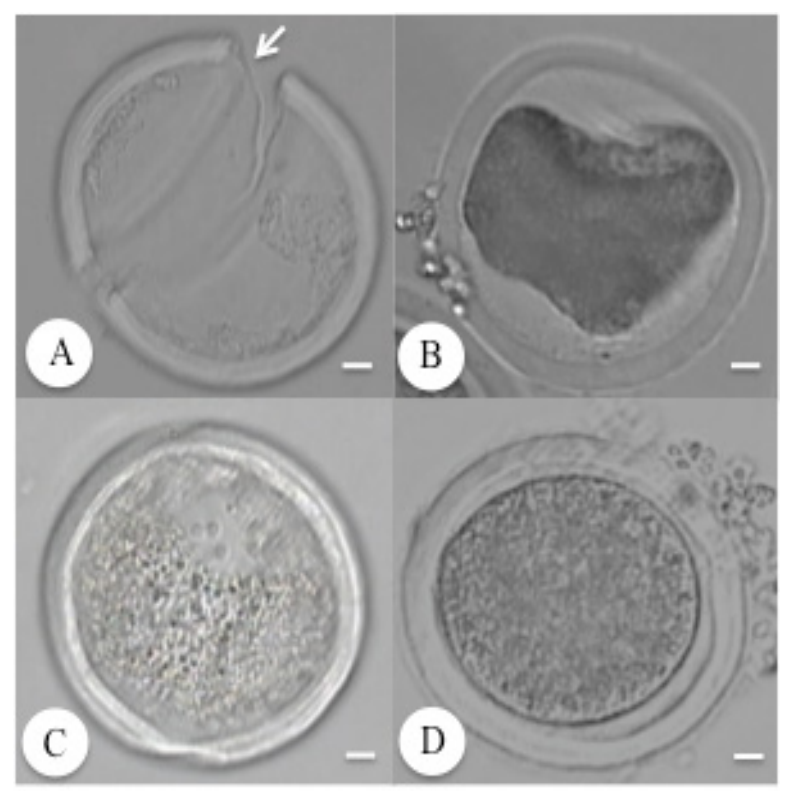

\section{Gambar Oosit Domba Pascavitrifikasi-warming}

A. Oosit dengan zona pelusida fraktur B. Oosit dengan penyusutan sitoplasma C. Oosit dengan sitoplasma yang lisis (A-C oosit yang mati). D. Oosit yang bertahan hidup skala bar: $10 \mu \mathrm{m}$

sitoplasma yang lisis. Oosit yang hidup ditandai dengan zona pelusida dan sitoplasma yang utuh setelah pencairan kembali dan 3 jam kultur (Gambar). Hasil observasi persentase oosit hidup pascavitrifikasi-pencairan kembali dapat diamati pada Tabel 1.

Hasilpenelitian menunjukkan bahwa terdapat perbedaan yang nyata pada persentase oosit hidup pascavitrifikasi-pencairan kembali antara perlakuan menggunakan 0,5 M sukrosa dan $0,65 \mathrm{M}$ sukrosa. Perlakuan dengan menggunakan 0,65M sukrosa 15\% EG+15\% DMSO diperoleh persentase oosit hidup yang lebih tinggi apabila dibanding dengan menggunakan 0,5 M sukrosa $(70,49 \%$ dibanding dengan $56,00 \%$, $\mathrm{p}<0,05)$. Selanjutnya, dilakukan pengamatan atas morfologi oosit yang mati pascavitrifikasipencairan kembali. Hasil pengamatan dapat dilihat pada Tabel 2 .
Hasil pengamatan memperlihatkan bahwa morfologi oosit yang mati pada oosit yang divitrifikasi menggunakan penambahan $0,5 \mathrm{M}$ sukrosa pada media vitrifikasi sebagian besar menunjukkan zona pelusida yang fraktur, sedangkan pada 0,65 M sukrosa sebagian besar menunjukkan oosit mengalami degenerasi. Analisis hasil statistik memperlihatkan bahwa terdapat perbedaan pada oosit yang mengalami fraktur zona pelusida yang nyata lebih tinggi pada oosit yang divitrifikasi dengan menggunakan 0,5 M sukrosa bila dibanding dengan yang mempergunakan $0,65 \quad M$ sukrosa $\quad(54,32 \%$ dibanding dengan 29,02\%, p<0,05). Morfologi oosit yang mengalami degenerasi secara statistik lebih rendah pada oosit yang divitrifikasi dengan penambahan 0,5 M sukrosa pada media vitrifikasi bila dibanding dengan penambahan 0,65 M sukrosa pada media vitrifikasi $(32,90 \%$

Tabel 1 Persentase Oosit Hidup Pascavitrifikasi-Pencairan Kembali pada Media Vitrifikasi dengan Penambahan Sukrosa dengan Dua Konsentrasi yang Berbeda

\begin{tabular}{lcc}
\hline \multicolumn{1}{c}{ Konsentrasi Sukrosa } & $\begin{array}{c}\text { Jumlah Oosit } \\
\text { (n) }\end{array}$ & $\begin{array}{c}\text { Persentase Oosit Hidup } \\
\text { Pascavirifikasi-Pencairan Kembali } \\
\text { ( \%) }\end{array}$ \\
\hline 0,5 M sukrosa & 71 & $38(56,00 \pm 4,35 \%)^{\mathrm{a}}$ \\
0,65 M sukrosa & 48 & $37(70,49 \pm 7,12 \%)^{\mathrm{b}}$ \\
\hline
\end{tabular}

Keterangan: superskrip ${ }^{\mathrm{a}, \mathrm{b}}$ menunjukkan perbedaan secara yang nyata secara statistik pada kolom yang sama 
Rini Widyastuti: Perbandingan Viabilitas Oosit Pascavitrifikasi pada Dua Tingkat Konsentrasi Sukrosa yang Berbeda

Tabel 2 Morfologi Oosit Mati Pascavitrifikasi-Pencairan Kembali pada Media Vitrifikasi dengan Penambahan Sukrosa dengan Dua Konsentrasi yang Berbeda

\begin{tabular}{ccccc}
\hline \multirow{2}{*}{$\begin{array}{c}\text { Konsentrasi } \\
\text { Sukrosa }\end{array}$} & Jumlah Oosit & \multicolumn{3}{c}{ Morfologi Oosit Mati (\%) } \\
\cline { 3 - 5 } & & Zona Pelucida Fraktur & Degenerasi & Total \\
\hline $0,5 \mathrm{M}$ & 71 & $20(54,32 \pm 3,22 \%)^{\mathrm{a}}$ & $11(32,90 \pm 3,22 \%)^{\mathrm{a}}$ & $33(46,00 \pm 4,35 \%)^{\mathrm{a}}$ \\
$0,65 \mathrm{M}$ & 48 & $4(29,02 \pm 11,79 \%)^{\mathrm{b}}$ & $8(66,67 \pm 11,79 \%)^{\mathrm{b}}$ & $11(29,51 \pm 7,12 \%)^{\mathrm{b}}$ \\
\hline
\end{tabular}

Keterangan: superskrip a,b menunjukkan perbedaan secara yang nyata secara statistik pada kolom yang sama

dibanding dengan $66,67 \%$, $\mathrm{p}<0,05)$. Hasil secara keseluruhan menunjukkan bahwa penggunaan $0,65 \mathrm{M}$ sukrosa memberikan hasil yang lebih baik dibanding dengan penambahan $0,5 \mathrm{M}$ sukosa pada media vitrifikasi. Hal ini telihat pada tingkat kematian oosit yang nyata lebih rendah pada penambahan $0,65 \mathrm{M}$ sukrosa dibanding dengan 0,5 M sukrosa, yaitu secara berurutan $29,66 \%$ dan $46,00 \%(\mathrm{p}<0,05)$.

\section{Pembahasan}

Kunci utama keberhasilan vitrifikasi adalah penggunaan krioprotektan dengan konsentrasi tinggi, laju kecepatan pembekuan, dan laju kecepatan pencairan kembali yang sangat tinggi $\left( \pm 20.000^{\circ} \mathrm{C} / \mathrm{min}\right)$. Efek krioprotektan yang paling penting adalah meminimalisir pembentukan kristal es dengan cara menjaga dari stabilitas membran (krioprotektan ekstraseluler) dan menggantikan cairan sitoplasma pada saat proses vitrifikasi (krioprotektan intraseluler). ${ }^{13}$ Sukrosa merupakan jenis krioprotektan ekstraseluler yang sering dipergunakan untuk vitrifikasi pada oosit maupun embrio. Pada penelitian ini digunakan dua macam konsentrasi sukrosa pada media vitrifikasi yang digunakan. Hasil yang diperoleh menunjukkan bahwa penggunaan sukrosa dengan konsentrasi 0,65 M memberikan hasil yang lebih baik apabila dibanding dengan penggunaan sukrosa 0,5 M. Persentase oosit hidup secara nyata lebih tinggi pada oosit yang divitrifikasi dengan penambahan $0,65 \mathrm{M}$ sukrosa pada media vitrifikasi apabila dibanding dengan penambahan 0,5 $\mathrm{M}$ sukrosa.

Pada konsentrasi 0,65 M, sukrosa lebih optimal dalam membantu stabilisasi membran oosit pada saat proses dehidrasi dan membantu krioprotektan intraseluler untuk masuk ke dalam oosit dan juga menggantikan cairan intraseluler pada saat proses dehidrasi itu berlangsung. Krioprotektan ekstraseluler akan membantu proses dehidrasi serta stabilisasi membran oosit sehingga tidak akan terjadi stres osmotik yang disebabkan oleh penggantian cairan intraseluler oleh krioprotektan intraseluler yang berlangsung dalam waktu sangat cepat. Selain itu, keberadaan krioprotektan ekstraseluler juga akan mengurangi terjadinya ekso-osmose atau pengeluaran cairan sel yang terlalu besar. Pemakaian krioprotektan ekstraseluler dalam konsentrasi yang optimal akan mencegah kerusakan morfologi oosit pada saat proses vitrifikasi. ${ }^{14,15}$.

Pada konsentrasi sukrosa 0,5 M, penggunaan sukrosa kurang mencukupi sehingga tidak mampu menjaga kestabilan membran oosit pada saat peristiwa dehidrasi. Akibatnya, oosit akan mengalami fraktur pada zona pelusida atau degenerasi. Faktor yang mengakibatkan kerusakan pada morfologi oosit selama proses vitrifikasi-pencairan kembali adalah kejutan dingin, pembentukan kristal es, dan kerusakan akibat fraktur. Pada kejutan dingin akan terjadi perubahan pada struktur membran dan mikrotubuli dari spindle oosit serta kerusakan pada sitoplasma. Kerusakan akibat pembentukan es pada saat proses pembekuan kemungkinan terjadi antara suhu $-5^{\circ} \mathrm{C}$ dan $-80^{\circ} \mathrm{C}$. Kristal es tersebut dapat terjadi pada media vitrfikasi yang ada di sekitar sel, di dalam sitoplasma maupun di dalam inti sel sehingga pembentukan kerusakan fraktur pada oosit dapat terjadi antara $-50^{\circ} \mathrm{C}$ dan $-150^{\circ} \mathrm{C}$ dikarenakan pengaruh mekanik dari oosit dan medium vitrifikasi. Jenis kerusakan lebih sering terjadi selama proses pencairan kembali (warming) dan mungkin dapat diminimalkan dengan mengurangi tingkat perubahan temperatur pada zona temperatur tersebut. Selain itu, kerusakan organel yang mungkin dapat terjadi pada vitrifikasi oosit adalah pengerasan zona pelusida, pelepasan granula kortikal yang prematur, depolimerasi mikrotubulus, dan juga kesalahan penyusunan kromosom.

Pada saat proses vitrifiksi maupun pencairan kembali, organel yang sangat rentan mengalami kerusakan adalah spindle apparatus. Kerusakan yang terjadi pada spindle apparatus tidak dapat 
kembali pada formasi awal sesuai dengan keadaan fisiologi pada saat sebelum divitrifikasi sehingga dalam proses vitrifikasi sangat penting untuk menjaga organel sel intraseluler tetap dalam kodisi yang baik. ${ }^{16}$

Pada pengamatan morfologi oosit yang mati pascavitrifikasi, morfologi oosit yang mati pada oosit yang divitrifikasi dengan penambahan 0,5 M sukrosa pada media vitrifikasi didominasi oleh zona pelusida yang fraktur $(54,32 \%)$. Kondisi ini menunjukkan bahwa penggunaan sukrosa 0,5 M menimbulkan dampak kerusakan ekstraseluler yang lebih banyak pada zona pelusida dibanding dengan perlakuan 0,65 M. Zona pelusida merupakan pelindung ekstraseluler yang relatif tebal $(1-25 \mu \mathrm{m})$ pada struktur oosit. ${ }^{17}$ Terjadinya kerusakan zona pelusida akan menyebabkan kerusakan organel di dalam ooplasma yang akan membuat oosit mati.

Kerusakan morfologi oosit setelah pencairan kembali pada penambahan 0,65 M sukrosa dalam media vitrifikasi didominasi oleh oosit yang mengalami degenerasi $(66,67 \%)$. Pecah dan frakturnya zona pelusida dan lisisnya oolemma adalah kerusakan morfologi yang paling jelas pada oosityang beku-dicairkan. ${ }^{18}$ Pada penelitian ini, persentase oosit hidup yang dibekukan menggunakan sukrosa dengan konsentrasi 0,5M lebih rendah apabila dibanding dengan hasil yang dicapai oleh Emeka, ${ }^{19}$ yaitu 87,8\%. Hal ini terjadi karena perbedaan jenis dan konsentrasi krioprotektan yang digunakan, yaitu kombinasi krioprotektan 0,5 M sukrosa + $5 \mathrm{M} \mathrm{PROH}$.

Abnormalitas oosit yang berkurang dengan cara mengombinasikan penggunaan sukrosa 0,65 M dalam larutan vitrifikasi. Konsentrasi krioprotektan (15\% etilen glikol $+15 \%$ DMSO) yang tinggi dalam larutan vitrifikasi mengurangi kemungkinan kristalisasi intraseluler yang dianggap menyebabkan kerusakan selama proses pembekuan cepat, tetapi juga dapat menyebabkan efek toksisitas dan stres osmotik pada oosit walaupun tanpa pendingin. Sukrosa sebagai krioprotektan ekstraseluler cenderung mengurangi efek toksisitas tersebut. Sukrosa sebagai molekul makro meningkatkan dehidrasi air dari sitoplasma dan langkah ini sangat penting dalam proses vitrifikasi. ${ }^{20}$ Akibatnya, sitoplasma oosit menyusut dan jumlah air di dalam oosit yang dapat mengkristal selama vitrifikasi dan pencairan kembali lebih rendah

Simpulan, berdasar atas hasil yang diperoleh pada penelitian ini dapat disimpulkan bahwa penggunaan sukrosa 0,65 $\mathrm{M}$ pada media vitrifikasi memberikan dampak yang lebih baik apabila dibanding dengan penambahan sukrosa
0,5 M di dalam mempertahankan morfologi dan viabilitas oosit selama proses vitrifikasipencairan kembali.

\section{Daftar Pustaka}

1. Stoop D, Cobo A, Silber S. Fertility preservation for age-related fertility decline. Lancet. 2014;384(9950):1311-9.

2. Arav A. Cryopreservation of oocytes and embryos. Theriogenology. 2014;81(1):96102.

3. Konc J, Kanyo K, Kriston R, Somoskoi B, Cseh S. Cryopreservation of embryos and oocytes in human assisted reproduction. BioMed Res Int. 2014;2014:307268.

4. Chaves DF, Souza-Fabjan JG, Mermillod P, Freitas VJF. Factors that affect oocyte vitrification in small ruminants. Revista Brasileira de Ciência Veterinária. 2014;21(2): 69-75.

5. Wu H, Yu X-L, Guo X-F, Zhang F, Pei X-Z, Li $\mathrm{X}-\mathrm{X}$, dkk. Effect of liquid helium vitrification on the ultrastructure and related gene expression of mature bovine oocytes after vitrifying at immature stage. Theriogenology. 2017;87:91-9.

6. Moussa M, Shu J, Zhang X, Zeng F. Cryopreservation of mammalian oocytes and embryos: current problems and future perspectives. Sci China Life Sci. 2014; 57(9):903-14.

7. Rusciano G, De Canditiis C, Zito G, Rubessa M, Roca MS, Carotenuto R, dkk. Ramanmicroscopy investigation of vitrificationinduced structural damages in mature bovine oocytes. PloS one. 2017;12(5):e0177677.

8. Paul AK, Liang Y, Nagai T, Parnpai R. In vitro development potentiality of expanded bovine blastocysts subsequent to cryotop vitrification. Thai J Veterinary Med. 2014; 44(4):513-21.

9. Seki S, Jin B, Mazur P. Extreme rapid warming yields high functional survivals of vitrified 8-cell mouse embryos even when suspended in a half-strength vitrification solution and cooled at moderate rates to- $196 \mathrm{C}$. Cryobiology. 2014;68(1):71-8.

10. Kuwayama M, Vatja G, Kato O, Leibo SP. Highly efficient vitrification method for cryopreservation of human oocytes. Reprod Biomed Online. 2005;11(3):100-8.

11. Widyastuti R, Rasad SD. Tingkat kematangan inti oosit sapi setelah 24 jam presevasi Ovarium. Jurnal Agripet. 2015 15(2):72-8. 
12. Hadi H, Wahid H. Mazni OA, Rosmina Y, Daliri M, Dashtizad M, dkk. Temperature on in vitro viability and subsequent embryo development of vitrified-warmed immature bovine oocytes. Am J Animal Veterinary Sci. 2010;5(2):71-5.

13. Davidson AF, Benson JD, Higgins AZ. Mathematically optimized cryoprotectant equilibration procedures for cryopreservation of human oocytes. Theoretical Biol Med Modelling. 2014; 11(13):2-19.

14. Sripunya N, Somfai T, Inaba Y, Nagai T, Imai K, Parnpai R. A comparison of cryotop and solid surface vitrification methods for the cryopreservation of in vitro matured bovine oocytes. J Reproduction Development. 2010; 56(1):176-81.

15. Zhang J, Nedambale TL, Yang M, Li J. Improved development of ovine matured oocyte following solid surface vitrification (SSV): effect of cumulus cells and cytoskeleton stabilizer. Animal Reproduction Sci. 2009; 110(1-2):46-55.
16. Varghese AC, Nagy ZP, Agarwal A. Current trends, biological foundations and future prospects of oocyte and embryo cryopreservation. Reproductive Biomed Online. 2009;19(1):126-40.

17. Wassarman PM.Zonapellucidaglycoproteins. J Biol Chem. 2008;283(36):24285-9.

18. Hosseini SM, Asgari V, Ostadhosseini S, Hajian M, Piryaei A, Najarasl M, dkk. Potential applications of sheep oocytes as affected by vitrification and in vitro aging. Theriogenology. 2012;77(9):1741-53.

19. Emeka C. Sucrose and propylene glycol effect on the vitrification of oocytes in sheep. Global J Animal Environmental Biol. 2015;3(1):2631.

20. Quan GB, Wu GQ, Wang YJ, Ma Y, Lv CR, Hong $\mathrm{QH}$. Meiotic maturation and developmental capability of ovine oocytes at germinal vesicle stage following vitrification using different cryodevices. Cryobiology. 2016;72(1):3340. 